\title{
OCCUPATIONAL SAFETY AND HEALTH REGULATION AT THE LOCAL LEVEL-COMPARISON OF LEGAL SOLUTIONS IN SERBIA AND MONTENEGRO
}

\author{
UDC 331.45:642.25(497.11+497.16)
}

\author{
Aleksandra Ilić Petković, Vesna Nikolić, Dejan Vasović \\ University of Niš, Faculty of Occupational Safety in Niš, Serbia
}

\begin{abstract}
Employees in local self-government units perform tasks of immediate interest for the local population, and their workplace safety and health is an important factor for the effective implementation of all policies at the local level. Given that there is not much research on the safety and health of employees in local self-government units in Serbia and Montenegro, there is a need for the analysis of the protection provided by the applicable regulations in the countries of this part of Europe. The conducted research shows that the right to safe and healthy working conditions in local selfgovernment units is governed by the regulations on workplace safety and health of those countries. It is desirable to improve the quality of legal protection which will contribute to the improvement of the workplace safety and health of these employees and will improve the quality of work in local self-governments.
\end{abstract}

Key words: occupational safety and health, local self-government, regulations

\section{INTRODUCTION}

In modern times the need for prevention and promotion of safe and healthy working conditions is evident since the maintenance of employees' health has an immeasurable effect on their productivity [1]. The main question is how to safeguard the complete integrity of the employee - physical, mental, and moral [2]. The answer to this question seems to be more complex when taking into account the existence of a whole variety of jobs that employees can perform. It is particularly important to ensure safe and healthy working conditions for employees who perform activities of vital interest for the functioning of the local community and local population at the level of local self-government units, which is relevant for human resource management at the local level [3]. There is no unified understanding of the concepts of local self-government and occupational safety and health. Local self-government refers to public administration tasks performed by public institutions

Received June 23, 2020 / Accepted October 5, 2020

Corresponding author: Aleksandra Ilić Petković

University of Niš, Faculty of Occupational Safety, Čarnojevića 10a, 18000 Niš, Serbia

E-mail: aleksa@ni.ac.rs 
at the local level, which are different from the tasks performed at the state level [4]. This refers to the right and opportunity for local authorities to regulate and manage a certain part of public affairs on the basis of their own responsibility, and in the interests of the local population, within the limits of the law [5]. It is a local management system aimed at harmonizing general and individual interests at the local level and protecting human rights and freedoms [6]. The local self-governments activities should contribute to improving the quality of life of the local population, with limited material, human and other resources at its disposal [7]. As regards occupational safety and health, many factors influence the understanding of this notion, such as the degree of development of socioeconomic relations, etc. [8]. Labor law theoreticians have a specific view of workplace protection. General protection is a system of measures and activities that prevent or mitigate the harmful effects of working conditions and work processes on the safety, health and working capacity of all employees. Special protection provides additional protection for young people, people with disabilities and health problems, pregnant women, etc. [9, 10, 11]. Both types of protection refer to physical, mental and moral integrity. As the activities carried out by the local self-government concern the vital interests of the local community, there is an indisputable need to pay special attention to the safety and health of the employees who perform these tasks. The improved quality of legal protection of these employees gives a special contribution to the work of the public administration as a whole [12]. The implementation of health protection in different policies can involve the action at several levels of government, but, indeed, the factors influencing the implementation of health protection in different policies at the local level are largely unexplored [13]. Since there is not much research on this topic, this paper will analyze the regulations on the labor status of employees in local self-government units and regulations on occupational safety and health in Serbia and Montenegro. Until recently, these countries formed an integral part of one state, but today each is independent and they are EU membership candidates [14]. Any idea that can contribute to the improvement of the occupational health and safety system is of great importance for these countries. This research will shed light on the need to legally regulate the occupational safety of several categories of employees, such as those who work in the public sector and public services. In international law, the rights of particular categories of employees are guaranteed by the EU and ILO regulations. According to EUOSHA, the EU has the directives which regulate the occupational safety of employees in the systems of health, traffic, construction and some industries [15]. Unlike the EU, the ILO has the conventions on employees in public services, however, these documents mainly refer to the right to association but not occupational safety and health [16]. This is why additional analysis of the legal regulation of occupational safety and health of employees in local self-government units is required.

\section{METHODS}

Content analysis was the method used for collecting and processing the data in this paper. It was used for the analysis of constitutional documents in Serbia and Montenegro in the parts pertaining to local self-government and occupational safety and health. This was followed by the analysis of the laws of the aforementioned countries and they were classified into two categories - laws regulating local self-government and labour status of the employees in local self-government and laws regulating occupational safety and 
health. The results obtained for these countries were compared. The authors first examined the results pertaining to constitutional documents, which was followed by the analysis of the laws.

\section{RESULTS}

Local self-government in Serbia is mentioned in the Constitution in various contexts, which contributes to its significance [17]. The employees in local self-government units are not specifically recognized in the Constitution. The Law on Local Self-Government [18] does not deal with persons' employment status in local self-government units and their workplace safety and health, but there are several provisions concerning the employment status in terms of the obligation or possibility of starting an employment relationship. The Law on Employees in Autonomous Provinces and Local Self-Government Units [19] stipulates which categories of persons are considered employees and determines the persons to whom it applies. Workplace safety and health of employees is one of the most important human rights and in Serbia it is guaranteed by the Constitution, which stipulates that everyone has the right to safe working conditions and necessary workplace safety [17]. The Law on Occupational Safety and Health is the basic Serbian regulation in this field [18]. As regards the occupational safety and health status of the employees in local self-government units, it can be noted that the Law on Occupational Safety and Health applies to these persons.

There are several provisions in the Constitution of Montenegro pertaining to selfgovernment (e.g. provisions on the President of the Municipality) [21]. The Law on Local Self-Government regulates the rights and responsibilities of the listed categories of persons, job classification and the titles of local officials and employees, etc.[22]. The Constitution of Montenegro guarantees the right to occupational safety [21]. The Law on Occupational Safety and Health [23] applies to all the employees in state bodies and state administration bodies, including the local self-government units. They apply to all persons who are present at their place of employment in any work process on any legal basis. The Law on Occupational Safety and Health determines the scope of persons entitled to occupational safety and prescribes that its provisions pertain to the employees in local self-government units. This law does not recognize the right to workplace safety and health of local officials, local civil servants and local employees. It prescribes that the law governing the establishment of the employment relationship in state bodies, the rights, obligations and responsibilities of civil servants and state employees, as well as general labor regulations, shall apply to the rights, obligations and responsibilities of these persons not regulated by this law. The Labor Law of Montenegro provides workplace safety and health [24].

\section{DISCUSSION AND CONCLUSION}

The Constitution of Serbia and the Law on Local Self-Government do not deal with employees in local self-government units and their occupational safety and health. The Law on Employees in Autonomous Provinces and Local Self-Government Units provide an overview of workplace safety and health, although it contains several provisions on this. The fact that the regulations on local self-government and employees in local selfgovernment units do not recognize the issue of workplace safety and health of their 
employees highlights the necessity of analyzing the regulations on occupational safety and health. The right to safe and healthy working conditions is guaranteed by the Constitution and elaborated on in the Law on Occupational Safety and Health which applies to the employees in local self-government units. The right to occupational safety and health is guaranteed to them by the Law on Employees in Autonomous Provinces and Local SelfGovernment Units as well. All these regulations guarantee the protection of physical integrity, but when one takes into account the nature of the tasks these persons perform, there is a much greater need to preserve their mental and moral integrity. This issue is somewhat regulated by other laws regarding the prohibition of discrimination, abuse at work, etc. [25, 26].

The Constitution of Montenegro and the Constitution of Serbia have a number of similar provisions pertaining to local self-government. Unlike Serbia, the Constitution of Montenegro contains some provisions on the employees in local self-government units. A significant difference in the regulation of the labor status of employees in local selfgovernment units between Serbia and Montenegro is that the Law on Local SelfGovernment in Montenegro regulates the labor status of these persons. In Serbia, this issue is regulated by a separate law. Both countries contain legal documents that methodically regulate the system of local self-government and the persons who work in it. In Serbia and Montenegro, the right to occupational safety and health is guaranteed by constitutional documents almost identically. None of their constitutions recognize the need for special protection of some categories of employees in local self-government. In Montenegro, the right to occupational safety is regulated by the Law on Occupational Safety and Health, which, like the Law on Occupational Safety and Health in Serbia, determines the scope of persons to whom it applies. There is one significant difference between the two laws - the Montenegrin law clearly stipulates that its provisions also apply to employees of local self-government units, while the Serbian Law on Occupational Safety and Health does not explicitly stipulate and prescribe this. The Law on Local SelfGovernment of Montenegro does not recognize the right to occupational safety and health of local officials, local civil servants and local employees, but implies the implementation of the Labor Law of Montenegro, which guarantees the safety and health of employees at work. This provision is almost identical in the Serbian Labor Law.

Bearing in mind that local self-government can be understood as the right and ability of local authorities to regulate and manage an extensive part of public affairs under their responsibility and in the interests of the local population, within the limits of the law [27], it is not insignificant who and how will perform the jobs in local self-government units. Values such as professionalism, efficiency and the like are expected from the employees in local self-government units, as well as the state employees [28], therefore, it is necessary to provide safe working conditions. Given that there is not much research on the safety and health of employees of local self-government units in the countries of Southeastern Europe, the analysis of their legal protection summarizes the advantages and disadvantages of existing regulations (Table 1).

Based on the conducted research, we can draw a number of conclusions. In the legal systems of Serbia and Montenegro employees in local self-government units are recognized as a separate category of employees whose employment status varies to a certain extent from general labor relations. The constitutional documents of these countries do not deal with the position of employees in local self-government units, but this issue is regulated at the level of legal documents. In Serbia, the employment status of these persons is regulated by the Law on Employees in Autonomous Provinces and Units of Local Self-Government 
Table 1 Overview of the regulations on occupational safety and health in local selfgovernment units in Serbia and Montenegro

\begin{tabular}{llll}
\hline State & $\begin{array}{l}\text { Regulations on local } \\
\text { self-government }\end{array}$ & $\begin{array}{l}\text { Regulations on the employees in } \\
\text { local self-government units }\end{array}$ & $\begin{array}{l}\text { Regulations on occupational } \\
\text { safety and health }\end{array}$ \\
\hline $\begin{array}{l}\text { Republic of } \\
\text { Serbia }\end{array}$ & $\begin{array}{l}\text { Law on Local } \\
\text { Self-Government }\end{array}$ & $\begin{array}{l}\text { Law on Employees in Autonomous } \\
\text { Provinces and Local Self- } \\
\text { Government Units }\end{array}$ & $\begin{array}{l}\text { Law on Occupational Safety } \\
\text { and Health }\end{array}$ \\
$\begin{array}{l}\text { Republic of } \\
\text { Montenegro }\end{array}$ & $\begin{array}{l}\text { Law on Local } \\
\text { Self-Government }\end{array}$ & Law on Local Self-Government & $\begin{array}{l}\text { Law on Occupational Safety } \\
\text { and Health }\end{array}$ \\
\hline
\end{tabular}

and in Montenegro by the Law on Local Self-Government. These laws are relatively new, which suggests that the legislator has only recently started to deal with the legal status of these persons. In these countries, there are special laws that regulate the issue of occupational safety and health, but none of these laws recognize employees in local selfgovernment units in a special way, as a category that requires additional protection. Moreover, the General Directive 89/391, although with some exceptions, does not recognize the need for special protection of employees in local self-government units either [29]. Employees in local self-government units should be especially protected in terms of their mental and moral integrity because the understanding of psychosocial factors of occupational safety would contribute to reducing injuries, diseases and absence from work [30]. Safety legislation in these countries should respond to the growing dangers of these two types of employee integrity, because work-related psychosocial risks can lead to deterioration of the mental health of employees, cardiovascular diseases and musculoskeletal organ disorders [31]. Also, the risk of workplace violence is becoming more frequent [32]. This would contribute to reducing the costs of occupational injuries and professional diseases, which, for example in the European Union amount to at least 476 billion euros a year [33].

Employees in local self-government units in Serbia and Montenegro enjoy a special employment status, which is regulated by special legal documents different from the general labor relations. Unlike labor legislation, workplace safety and health of the employees in local self-government units of these countries are not regulated by special documents, nor are these persons recognized as special categories of employees in any way. Here there is room for improvement of legislation in the form of bylaws because these categories of employees could be treated in a special way, given the nature of the jobs they perform. This shall be an additional contribution to the modernization of local self-government [34] in keeping with the current trend of efficient use of human and material resources [35], as well as to the much-needed health promotion [7] in these countries. The improvement of legal regulations will result in better performance of employees [36] since the development of local self-government depends on social and personal factors [37], all of which will contribute to its better functioning.

Acknowledgement: This research was funded by the Ministry of Education, Science and Technological Development of the Republic of Serbia. 


\section{REFERENCES}

1. Strategic Framework on Health and Safety at Work 2014-2020, Available at http://eur-lex.europa.eu/ legal-content/EN/TXT/?uri=COM:2014:332:FIN (14.5.2020)

2. Neves P., Do Ceu M., On (Scientific) Integrity: Conceptual Clarification, Medicine health care and philosophy, vol. 212, 2018, pp. 181-187.

3. Perlman B., Human Resource Management at the Local Level: Strategic Thinking and Tactical Action, State and Local Government Review, vol. 48, 2016, pp. 114-120.

4. Pospíšil P., Lebiedzik M., Some of the Theoretical Basis of Local Self-government in the Czech Republic, Danube: Law and Economics Review, vol. 8, 2017, pp. 31-43.

5. Ilić M., (2013), Local Self-Government, Faculty of Education, Vranje.

6. Dimitrijević P., Vučetić D., (2011), The System of Local Self-Government, PC Official Gazette, Belgrade.

7. Gecíková I., Papcunová V., Using of Strategic Management Tools in Conditions of Local SelfGovernment in Slovakia, Procedia - Scotland Behavioral Sciences, vol. 110, 2014, pp. 969-978.

8. Anđelković B., (2010), Basics of the Protection System, Faculty of Occupational Safety, Niš.

9. Kulić Ž., Stojičić S., (2016), Labor Law, Institute for Textbooks, Belgrade.

10. Jovanović P., (2015), Labor Law, Faculty of Law, Novi Sad.

11. Ivošević Z., (2007), Labor Law, Official Gazette, Belgrade.

12. Glennon R. et al., Public Sector "Modernisation": Examining the Impact of a Change Agenda on Local Government Employees in England, Australian Journal of Public Administration, vol. 77, 2018, pp. 203-221.

13. Guglielmin M. et al., A Scoping Review of the Implementation of Health in All Policies at the Local Level, Health Policy, vol. 122, 2018, pp. 284-292, 2018.

14. Stanković M., Milisavljević B., Reform of Local Self-government in Serbia - Internal Legal Framework and EU Integration, Lex localis, vol. 16, 2018, pp. 25-45.

15. EU OSHA, Sector-specific and worker related provisions, Available at https://osha.europa.eu/en/ legislation/directives/sector-specific-and-worker-related-provisions (1.5.2020)

16. ILO, Public service sector, Available at https://www.ilo.org/global/industries-and-sectors/public-service/ lang--en/index.htm (1.5.2020)

17. Constitution of the Republic of Serbia, Available at http://www.paragraf.rs/propisi/ustav_republike_ srbije.html (5.5.2020)

18. Law on Local Self-Government of the Republic of Serbia, Available at http://www.mduls.gov.rs/doc/ dokumenta/Zakon\%20o\%20lokalnoj\%20samoupravi.pdf (11.5.2020)

19. Law on Employees in Autonomous Provinces and Local Self-Government Units of the Republic of Serbia, Available at http://www.mduls.gov.rs/doc/dokumenta/Zakon\%20o\%20zaposlenima\%20u\% 20autonomnim\%20pokrajinama\%20i\%20jedinicama\%20lokalne\%20samouprave.pdf. (11.5.2020)

20. Law on Occupational Safety and Health of the Republic of Serbia, Available at https://www.minrzs.gov. rs/files/doc/bezbednost_na_radu/Dopuna_Nov/Zakon_o_bezbednosti_i_zdravlju_na_radu_nezvanicno_p reciscen_tekst.pdf. (21.5.2020)

21. Constitution of the Republic of Montenegro, Available at http://www.skupstina.me/images/dokumenti/ ustav-crne-gore.pdf. (21.5.2020)

22. Law on Local Self-Government of the Republic of Montenegro, Available at http://www.mju.gov.me/ biblioteka/zakoni. (19.5.2020)

23. Law on Occupational Safety and Health of the Republic of Montenegro, Available at http://www.mju. gov.me/biblioteka/zakoni. (18.5.2020)

24. Labor Law of the Republic of Montenegro, Available at http://www.mju.gov.me/biblioteka/zakoni. (20.5.2020)

25. Law on the Prevention of Harassment at the Workplace of the Republic of Serbia, Available at https://www.minrzs.gov.rs/sektor-za-rad-zakoni.html. (15.6.2020)

26. Law on the Prohibition of Discrimination of the Republic of Serbia, Available at https://www.minrzs. gov.rs/dokumenti-7968.html. (5.6.2020)

27. Demmke C., (2005), Are Civil Servants Different Because They are Civil Servants?, European Institute of Public Administration, Luxembourg.

28. European Charter of Local Self-government, Available at https://rm.coe.int/168007a088 (20.6.2020)

29. Directive 89/391/EEC - OSH "Framework Directive, Available from: https://osha.europa.eu/en/ legislation/directives/the-osh-framework-directive/1 (20.6.2020).

30. Slany C. at al., Psychosocial Work Factors and Long Sickness Absence in Europe, International Journal of Occupational and Environmental Health, vol. 20, 2014, pp. 1-25.

31. European Agency for Occupational safety and health (EU-OSHA), Management of psychosocial risks in European workplaces - evidence from the second European survey of enterprises on new and emerging risks (ESENER-2) - Executive summary, EU-OSHA, Bilbao, 2018. Available at https://osha.europa.eu/ 
en/publications/management-psychosocial-risks-european-workplaces-evidence-second-european-survey/ view (20.5.2020).

32. Robbins K., Workplace Violence - The Joint Commission's Sentinel Alert, Nephrology Nursing Journal, vol. 45, 2018, pp. 291-293.

33. European Agency for Occupational safety and health (EU-OSHA), An international comparison of the cost of work-related accidents and illnesses, EU-OSHA, Bilbao, 2017, Available at https://osha.europa. eu/en/publications/international-comparison-cost-work-related-accidents-and-illnesses/view (20.6.2020).

34. Copus C., Steyvers K., Local Leadership and Local Self-government: Avoiding the Abyss, Lex Localis, vol. 15, 2017, pp. 1-18.

35. Santrić Milicević M. et al., Strengthening the public health workforce: An estimation of the long-term requirements for public health specialists in Serbia, Health Policy, vol. 122, 2018, pp. 674-680.

36. Lozina D.,. Klarić M, Local Public Servants and Employees in the Republic of Croatia: Legal Position and Obligations, Lex Localis, vol. 6, 2008, pp. 413 - 428.

37. Arsenijević O., Kastratović E., Nešić S., Attitudes of the Employees on Education in Local-SelfGovernment, Economic Analysis, vol. 50, 2017, pp. 77-96.

\section{PROPISI O BEZBEDNOSTI I ZDRAVLJU NA RADU NA LOKALNOM NIVOU - POREĐENJE PRAVNIH REŠENJA U SRBIJI I CRNOJ GORI}

Zaposleni u jedinicama lokalne samouprave obavljaju poslove od neposrednog interesa lokalnog stanovništva i njihova bezbednost i zdravlje na radu je važan preduslov efikasne implementacije svih politika na lokalnom nivou. Kako nema mnogo istraživanja o bezbednosti $i$ zdravlju na radu zaposlenih u jedinicama lokalne samouprave u Srbiji i Crnoj Gori, postoji potreba za analizom zaštite obezbeđene važećom regulativom u državama ovog dela Evrope. Sprovedeno istraživanje pokazuje da pravo na bezbednost $i$ zdravlje na radu u zaposlenih u jedinicama lokalne samouprave je garantovano propisima o bezbednosti $i$ zdravlju na radu u ovim državama. Poželjno je unaprediti kvalitet ove pravne zaštite što bi doprinelo unapređenju bezbednosti i zdravlja na radu ovih zaposlenih, a, samim tim, $i$ kvaliteta rada jedinica lokalne samouprave.

Ključne reči: bezbednost i zdravlje na radu, lokalna samouprava, propisi 